\title{
Decentralising Unitary Governments Without a Map: Learning How to Salsa When We Only Know How to Waltz
}

\author{
Jill L. Tao* \\ UDK: \\ 35.071.6(510:519.5) \\ Original scientific paper / izvorni znanstveni rad \\ Received / primljeno: 30. 12. 2015. \\ Accepted / prihvaćeno: 16. 12. 2016.
}

This paper examines disparities between unitary central governments and local governments in how environmental policy is defined and implemented at the local level. This is done within the context of northeast Asia, where results can often differ from expectations driven by traditional models of local government behaviour offered by the West. A theoretical measure for policy distance between the central government and its subsidiaries is constructed and then operationalised in a comparative context within northeastern China and the Republic of Korea. Using local and national budget data from 23 cities with histories of environmental issues (13 in northeast China and 10 in South Korea), the author's measure of policy distance between the centre and the periphery is tested. The paper finds that, contrary to traditional model expectations,

* Jill L. Tao, Associate Professor, Dean of the Office of International Affairs, Incheon National University, South Korea (izvanredna profesorica, voditeljica Ureda za međunarodnu suradnju Nacionalnog sveučilišta Incheon, Južna Koreja, e-mail: j.tao.808@gmail.com).

This work was supported by the Incheon National University (International Cooperative) Research Grant in 2015-2016. 
there is far greater concurrence between local governments and the national government within a democratic nation than there is within a communist one.

Keywords: decentralisation, local government, China, South

Korea, policy distance

\section{Introduction}

The current premier of the People's Republic of China, Li Keqiang, has signalled a renewed emphasis on reconciling rapid economic growth with environmental concerns. "[We] declare war against pollution as we declared war against poverty," was the key point made by Premier Li to 3,000 delegates in Beijing in March 2014, as he presented the coming year's priorities (Saikawa, 2014). Now, there is a new focus on the role of local governments which must "take responsibility for the quality of their environments". The central government has watched cities continually fall short of their monitoring benchmarks for pollution, and so a "new approach" is being tested.

This new approach, however, does not differ substantively from the previous approach. The central government has told local officials what their policy goals are (pollution reduction and caps on levels), but they have not outlined how this goal is to be achieved. Consequently, each local government is left to its own devices to discover how (and by how much) pollution can be reduced within its own jurisdiction. This mirrors, in many ways, the situation in South Korea, China's neighbour to the east, where local governments have been the enforcers of national pollution reduction policies for the past twenty years. South Korea has also taken the somewhat uncharacteristic step (from a unitary system perspective) of delegating all regulatory activity to the local level (Lee, Kim \& Ahn, 1999). In districts that have seen rapid industrialisation over the past thirty years, local fortunes have been made as deals have been struck between political and economic elites. Hence the question of which interest - that of the national government, of local economic elites, or the local public - is most likely to influence the local governments' response remains unanswered. As both countries try to move towards a post-industrial economy, the chance for new coalitions to be built at the local level is also rising.

The paper examines two different approaches to understanding national ㅇ influence over local governments when faced with a policy mandate in a 
newly decentralised implementation environment. First, it presents the commonly used policy models that are borrowed by Chinese and Korean scholars with graduate training in the West, but which often fall short in terms of providing the appropriate theoretical constructs when applied to the context of their home countries. Second, starting with an examination of model assumptions that are often violated in these contexts, it looks at other literatures to try and build a new set of expectations based on the conditions in East Asia. It examines the context of local government decision-making in northeast China, a region that has a long history of heavy industry and coincident environmental cost. It compares this history to that of South Korea, where industrial restructuring has begun to incorporate the environmental concerns that China is currently voicing. Finally, using local government environmental expenditures data, the paper outlines the recent behaviour of local officials in both countries to see how they respond to local constituencies, rather than central authority. Using this data, a measure of "policy distance" between the centre and local governments is constructed, and it is argued that this measure can be used in a comparative context to judge the relative influence of the centre over the periphery in a given policy area. The measure indicates that Chinese local government officials are less responsive to (and further from) changes in the centre with regard to environmental policy, whereas Korean local government officials are closer, on average, to the national government's lead.

After testing the premise of policy distance in the two countries, the discussion goes back to the issue of appropriate interpretation of the results, given the contexts in which the model has been tested. The paper concludes that the different contexts of Korea and China lead to an important distinction in the way in which local officials respond to national mandates in the two nations: Korean officials orient themselves towards the centre (vertical orientation), but Chinese officials orient themselves towards those of similar rank in other local governments (horizontal orientation) with whom they have established a solid historical relationship (Lee, 1998; Li, 2010). Thus the behaviour of local officials may not be interpreted in the same fashion as might be the case in a competitive local government "market".

\section{Incentive Structures from the Centre to the Periphery: A Brief Review of the Literature}

The way in which local government interactions are structured with a national government and with each other is theorised differently in Euro- 
pean and US contexts. However, these distinctions are often overlooked in countries outside the West, when scholars are looking for a theoretical framework that may help them better understand their own local government behaviour. As indigenous theories of local government behaviour in East Asia are still being developed, many studies (in English) of local government behaviour in China and South Korea borrow and test theories that have been developed in the West. This has led to somewhat unusual findings in the research conducted in these countries, partly because the nature of theoretical assumptions is often misunderstood or not known prior to the attempt to test these theories in new contexts. Here, the theories that are most often used (or abused) in East Asian contexts, including Japan ${ }^{1}$ are briefly summarised, and the ways in which this might be remedied in future research are highlighted.

\subsection{From Coordinating, Inclusive, and Overlapping Authority to Competition, Neoliberal Urban Economies, and Lateral Orientations}

Central-local relationships. Deil Wright's (1978) seminal work on intergovernmental relations (IGR) seemed to find its place in the East Asian lexicon in the late 1980s in Japan, at a time when Japanese academics like Michio Muramatsu (1997) and Mikiko Iwasaki (1985) were challenging the orthodoxy of older Japanese theorists. For Muramatsu especially, Wright's model of inclusive authority seemed a much better fit for Japanese central-local relations than the prevailing theories of the time. Those theories suffered from a lack of context, which he argued could only be arrived at in a comparative analysis. As he puts it: "It is interesting that both the United States and Japan are strongly imbued with the ideology of local government as independent from the state. In Japan, because the demands of local governing bodies have come to be understood as part of a pressure group process, in competition with the various other demands, there is a tendency for local government to justify itself through the freedom to oppose the state. Here, a divergence between theory (autonomy from the state) and reality (autonomy vis-à-vis the state) arises. Thus the 'theories' advocated make the understanding of the reality vague." (Muramatsu, 1997, p. 7).

\footnotetext{
${ }^{1}$ The intergovernmental literature from Japan is included here for perspective only.
} 
Muramatsu's conclusion that central-local relationships in unitary developed states, such as Japan and South Korea, could be comparable to those outlined in Wright's model was important. However, he made it clear that such a comparison was only appropriate in case of certain adjustments for the unique circumstances of post-World War II development in Japan's different spheres of power: political, administrative, and economic. For Japan, the increasingly important role of political parties as a mechanism to link central-local relations has countered, to some extent, the administrative power of the central government (Muramatsu, 1997, p. 26).

Choi and Wright (2004) note that Japan and South Korea share many common historical traits. Thus the conclusions that Muramatsu draws about the inclusive authority model might also be considered appropriate for South Korea. However, South Korea's dalliance with popular sovereignty has been far more fickle than that of Japan, and the result in South Korea is a political landscape that is markedly regionalised in terms of party dominance, with different political parties drawing on local strongholds for national support. This often results in a relatively muted impact of political party affiliations with respect to local budget priorities. In contrast, the administrative apparatus maintains tight control over local administrative behaviour, and as such, local civil servants tend to focus on the national government's directives regardless of the party majority of local level politicians (Choi \& Wright, 2004, p. 9). Such behaviour has been ascribed to certain cultural constructs, such as the heavy Confucian influence on civil servants in South Korea (Im, Campbell \& Cha, 2013).

China, as neither a developed state nor a democratic one, has not dabbled with Wright's IGR model, and Chinese scholars have remained silent regarding its utility for the Chinese context. Part of the reason for this silence is the current interpretation of "federalism" by the Communist Party leadership (Bristow, 2011) as being somewhat synonymous with pro-democracy factions. Li (2010) illustrates the substantial divide between China and its neighbours with respect to the inclusive authority model. As a communist state, the boundaries between economic, political, and administrative behaviour are markedly different from those of a democratic system. The constant tension between the forces of centralisation and decentralisation has been a recurring theme in East Asia, but in China especially, due to its geographic size and dense population. Where the inclusive authority model emphasises links between both the central government and each of the lower levels, within China, the nature of these links is political and ideological, where a Communist Party 
official may serve alongside a mayor or provincial governor to ensure that decisions are made in keeping with party doctrine. Thus central power is exercised through the Party and its representatives, who are also strategically placed throughout the administrative apparatus of the state. Enforcement of central mandates is therefore carried out through a combination of sanctions (threats) and incentives (promotions). Over time, however, administrative power has slowly shifted to the provinces $(\mathrm{Li}$, 2010), with some provincial governments enjoying increased jurisdiction over implementation of central decisions. This has been true of fiscal relations as well ( $\mathrm{Li}, 2010)$.

To summarise, one of the central shortcomings of using an intergovernmental model such as Wright's in the South Korean and Chinese contexts has been the lack of a universal suffrage mechanism (until recently in South $\mathrm{Korea}^{2}$ ) for choosing subnational political representatives. This is one of the reasons why scholars from these countries do not necessarily see the IGR models as an appropriate fit, and why China and SouthKorean differ from its East Asian neighbour, Japan.

Local-local relations. Local government theory, on the other hand, has been a far more popular body of literature for South Korean and Chinese academics. In particular, the so-called "neo-liberal" theories of local government behaviour have sparked considerable interest. Beginning with Charles Tiebout in 1956 (Tiebout, 1956), and continuing with Paul Peterson in 1981 and 1995 (Peterson, 1981; Peterson, 1995), theories of local government behaviour from the United States have been turned "inside out". Previous theoretical models of local government decision-making focused on dynamics that were internal to cities: political coalitions, elite politics, pluralistic models on a city scale, party politics, and even bureaucratic decision-making. Many of these models still dominate the literature on local government behaviour (Stone, 2008; Dahl, 1961; Lowi, 1969), and most focus solely on the internal dynamics of city governments and the variables that may explain the kinds of policy decisions and implementation choices such governments make. In countries lacking a strong local government democratic apparatus, however, the more recent theories hold more promise.

Building on Tiebout's thesis, Peterson (1981) argued that "internal" models treat city governments as if they were "nation states", and that this cre-

\footnotetext{
${ }^{2}$ Local governments held elections for local posts for the first time in 1995, again in 1998, and every four years since (Choi \& Wright, 2004).
} 
ated fundamental flaws in the conclusions drawn from the research. First and foremost was the issue of jurisdiction and boundary control: nation states often control their boundaries and can regulate the flow of people, goods, and capital across their borders, while cities, or local governments, cannot. This means that local governments are limited in their ability to control whether or not desirable residents (the median taxpayers) stay or go. Tiebout theorises that this sets up a competition amongst city governments to maximise their share of these residents, and Peterson argues that this drives the kinds of policies local governments will then pursue: allocative where distributions of public goods and resources are dispersed fairly uniformly throughout the local government's jurisdiction, but not redistributive.

This model has two main characteristics that are salient in the context of this analysis. First, cities compete with each other for median taxpayers, but not in a completely laissez faire manner. Cities compete within "tiers", or within a certain peer group (Minkoff, 2012), so that there are layers of competition, usually dictated by the size and complexity of the local economy. So, for example, Cincinnati might compete with Buffalo, but neither of them would compete with New York City. Second, because local governments have limits on their ability to keep residents from leaving (restrictions on movement), they focus on incentives enacted through policy selection. So Cincinnati might pay a great deal of attention to the "bundle of services" offered by Buffalo to its residents so that it may offer a similar or better (if possible) mix. In the US, this model has gained a great deal of currency, and has been demonstrated to predict policy choices at the local level with a much better level of explanatory power than the previous "internal" models. It has also formed the basis for a number of current models that are being tested increasingly in contexts outside of the US (Tavares \& Carr, 2013; Feiock, Francis \& Kassekert, 2010), with some degree of success.

However, within the European context, other models are often used to explain local behaviour, where the assumption of a stronger relationship between national and local governments can be fulfilled (e.g. Johansson, Niklasson \& Persson, 2015). It should be noted that "stronger" does not necessarily mean top-down, where the initiative comes from a national government and local governments are simple instructed delegates (Nakamura \& Smallwood, 1980). The local level can often be the initiator, but the national government plays an important role in how far the local initiative may be taken. Such models often focus on both the political and the administrative behaviour within a local government, but assume some 
degree of structural uniformity across jurisdictions within a particular nation-state. In this sense, European models differ from their US counterparts, where there is considerable variation in the structure of elections, jurisdictions, and the administrative apparatus of local government (district vs. at-large elections, strong mayor vs. council-manager administrations, patronage vs. professional administrations, e.g. Tao \& Feiock, 1999). So, although there is considerable variation throughout Western Europe, the way in which local government behaviour is examined and framed does not necessarily focus on structural variation of this kind, nor does it always focus on policy typologies at the local level (Peters, Schroter \& Maravic, 2015). However, there is an acknowledgement that local governments do pay attention to what other local governments do. This lateral orientation, while distinct in nature from the US context, is still a valid characteristic of the models used to predict behaviour.

It should also be noted that a lateral orientation does not necessarily mean competitive. Cooperation across local jurisdictions in the provision of public services, as outlined in the inter-local collective action (ICA) model (Clingermayer \& Feiock, 2001), may be preferable to competition in the case of local governments that find themselves strapped for funds and lacking the expertise necessary to provide what their constituents need. Thus the behaviour of local governments can be simultaneously competitive (within their tier) and cooperative (a central city and smaller surrounding suburbs, for example). The reason this distinction is important is because each set of theories is, of course, predicated on the examples and cases with which researchers in different geographies are familiar. Thus when we "borrow" a theoretical model to test it in a new context, we need to remain mindful of the assumptions that are built into the model and ensure that we do not violate a fundamental premise that renders our empirical investigation moot. This becomes somewhat problematic when we venture into contexts that are unfamiliar, or where the existing assumptions are poorly understood.

This can be demonstrated by a brief example from the South Korean literature on local government behaviour. Many academics in South Korea do their graduate work in the US, and therefore learn theoretical models that are appropriate and testable within the US context. But there is often a temptation to take a model that has gained currency in the literature (for example, the "neighbours" policy adoption thesis, Berry \& Berry, 1990) and import the model into the Korean context in order to test it. While such ambition is to be applauded, care must be taken to uphold the fundamental principles often outlined in comparative analyses. 
The "neighbours" thesis posits that local governments (or states/provinces) will look at what their neighbours do, and policy adoptions will often spread geographically as one locality (or state/province) demonstrates success. There is no reason to believe that this might not be the case in South Korea, except for the violation of two assumptions of the model: first, the model assumes that the subnational government has a certain degree of autonomy and policy edicts do not have to come from the national government; second, the model assumes that local governments orient themselves towards each other (as one might expect in a competitive environment). However, neither of these assumptions is supported within the Korean context. South Korea, as is mentioned in the introduction, has a unitary form of government, which means that local governments are structurally smaller versions of the national government, and each has a similar administrative and jurisdictional function. Policy areas are dictated by the centre and this dictation is enforced in budgetary terms, where local governments are not responsible for creating new policy. So the idea of a lateral orientation where local governments cooperate or compete with each other is not supported at all. Additionally, because policy edicts are issued by the central government, local governments tend to orient themselves towards the centre, rather than towards each other. Thus a "neighbours" thesis is simply untenable in the South Korean context.

So, an examination of relevant models that may be applicable to the South Korean and Chinese models needs to be careful to include the assumptions on which the models are premised. The following section will focus on the way in which unitary systems may be addressed, given the literature on such systems. This will include brief explications of the South Korean and Chinese contexts, so that the appropriateness of a given model can be seen.

\section{Brief Review of Recent History in Northeast China and the Republic of Korea}

The northeast provinces of modern China border Russia to the north and North Korea to the east, and their economic and political history is therefore firmly tied to the development models of the former Soviet Union (Wang et al., 2014). In the early 1950s, after the establishment of the People's Republic of China in 1949, the adoption of a Stalinist industrialisation model began in the northeast of China, where expertise and materials for 
constructing large-scale factories for the production of steel, coal refineries, and other building blocks for industrial development were close at hand. The Japanese occupation of these areas had also initiated the process of extraction of natural resources, which was continued under Mao Zhe Dong's "Great Leap Forward" policy, to try and pull China's largely agrarian society into the industrial age (Wang et al, 2014; Bianco, 1971).

The industrialisation process was concentrated in the Liaoning, Heilongjiang, and Jilin provinces, with several of the major cities there, such as Shenyang and Benxi, becoming synonymous with industrial prowess (Wang et al., 2014). But such prowess came at a considerable environmental cost. In the fall of 1988, a foreign language expert posted to the city of Benxi to help train university students and professors in English proficiency was greeted enthusiastically by the city's major, who said with great pride, "Welcome to the city of Benxi, the most polluted city in China!"3 Benxi, like most cities in the region, burned coal to provide heat during the winter, for cooking purposes in homes, and to provide electricity. As industry grew and demands for power increased, the burning of coal as the main source of energy meant that the air quality in most industrial areas resembled that of London during the $19^{\text {th }}$ century, where the smog was so thick, it resembled "pea soup" (Strebel \& Lehman, 2013). By the mid-1980s, resource depletion and the use of coal for energy had created constant problems with air quality, but there was little indication from the government that such issues posed health hazards to the population. However, China was by no means alone in its approach to industrial development.

O In the Republic of Korea, during the 1960s and '70s, when the country was ruled by Park Chung-hee, father of the current president, Park Geun Hye, the push to do the same - namely to industrialise the largely agricultural south of the Korean peninsula - was pursued with almost messianic fervour (Chapin, 1969). The motivation came from the need to provide opportunities for economic advancement to the population, especially in comparison to the more advanced (at that time) north. But the Republic of Korea had virtually no natural resources upon which it could draw to achieve its goals; all natural resources were located to the north of the $38^{\text {th }}$ parallel. So, the government of Park Chung-hee drew on its relationships with Japan and the US, its closest allies, in order to pursue its economic development goals. 
Both countries were successful in bringing industrialisation to their populations, but both paid the environmental costs for doing so. Pollution of drinking water, air quality degradation, and soil contamination are all issues that have led to increasing mortality rates in both countries for incidences of stomach and lung cancer. Lung cancer is currently the number one cause of cancer-related deaths in China, and all cancers are now the leading cause of death in South Korea (Jung et al., 2012; Chen et al., 2015), with rates continuing to rise over time. However, the need for a policy response in either country had not been recognised until relatively recently. This has proceeded in somewhat different ways in the two countries, and therefore, I will examine those differences in the following section on environmental factors.

\section{Terra Incognita: There Be Dragons}

Unitary governments, by definition, tolerate a limited policy distance between the central government and localities when compared to more pluralistic systems. However, there can be quite a bit of variation in how central policies are realised in the peripheral regions, depending on a number of important factors. The literature on decentralisation and devolution has outlined such factors repeatedly, but some have been the focus of greater attention than others. Here, some of the political, institutional, and economic factors are reviewed that prove particularly important when addressing unitary systems.

\subsection{Political Factors}

The role of political parties and ideology in unitary systems cannot be overstated. Even in a "one-party" system, the differences between factions within the same party can be substantial. This can often play out in the public sphere through the different media outlets for the different ideological factions within a party. In a unitary system with competitive political parties, such as South Korea, such outlets sometimes follow partisan lines but may also be affiliated with an ideological slant. This can mean that one gets markedly different takes on national policy depending on which media source one reads. By reading several, one can become aware of intraparty disputes as well as interparty disagreement. 
In the case of policy issues that have a geographical dimension, as most decentralisation issues do, the media can take on an important role in shaping local opinion as well as informing it. Regional politics can play out in local media outlets that do not always get airplay in the capital (Kwok et al., 2002). Thus one of the ways in which policy distance between the centre and the periphery can be assessed is to examine how a central policy is portrayed in local media outlets, especially those that share ideological or partisan ties to the ruling central party. The stronger the criticism or disagreement voiced at the local level, the greater the distance between the two.

Another political factor of importance is the power of local interests. Parties may be one such power, but in environmental policy there are other interests that traditionally play important roles. Industry, especially that which employs a large workforce but may also generate a great deal of pollution, can be quick to pressure a local government that is seen as "overzealous" in its enforcement of environmental regulations. This relationship can be further complicated by strong ties between state (or formerly state-owned) industries and local government officials. This is a problem in China and South Korea, where state support of industry has made local governments both de jure and de facto partners. This kind of pressure is presumed to be constant and strong in both countries, and especially tied to the economic well-being of the industry in question.

Grassroots groups can also bring pressure to bear on local officials, especially if they see public health being jeopardised by a lax approach to enforcement. If both are present, local officials have to either find a way to placate both, or choose a side and defend it. This kind of pressure can combine with the existing partisan and ideological landscape to produce local government behaviour that may deviate from central policy, creating a greater policy distance.

However, in both China and South Korea, the type of "local interest" has only recently begun to include what might be considered "citizen groups" or "grassroots organisations", and the nature of these groups is distinct across the two countries. In China, there are citizen "committees" that are meant to communicate local problems to party officials so that an appropriate response can be rendered at the appropriate level. ${ }^{4}$ Thus the committees fit into the apparatus of the state in a way that is somewhat

\footnotetext{
${ }^{4}$ Sun H. (2014). Interviews in Incheon, South Korea on November 15 and December
} 3. 
distinct from traditional notions of "citizen" or "grassroots" groups. These committees are meant to voice concerns, and, in earlier periods (during the Cultural Revolution), were meant to criticise "societal elements" that were not ideologically pure (Bianco, 1971). In more recent periods, such committees, mindful of their former reputation for brutality, have taken a somewhat softer tone (Fewsmith, 2000), and although members are expected to hear complaints, they do not expect challenges to the ruling structure, especially in larger urban areas.

The northeastern region of China, especially Liaoning Province, has been the site of forays into more democratic kinds of arrangements. Local elections have been held on a regular basis since the late 1990s, and an ongoing dialogue between local officials and the population has resulted in interesting policy developments in some cities within this region (Wang et al., 2014). However, these forays have largely occurred within the membership of the Chinese Communist Party (CCP), so although many official residents have been able to participate as voters, the selection of candidates is still tightly controlled. Increasingly, international non-governmental organisations (INGOs) have been quietly making appearances within the region, but their influence on policy is difficult to gauge. They do, however, provide a means for "fact-checking" the central government's claims about the impact of policy. Greenpeace, for example, monitors air quality across China, and they have independently verified China's claims to be making progress on air quality problems, using satellite data (Greenpeace, 2016).

In South Korea, the rise of local groups is often seen as intensely "political" in a way that is closer to the vernacular use of the word - politics is personal, and is built on networks of personal relations that are woven throughout society. Thus any kind of local group that is created to address a shared problem is naturally assumed to draw on a particular network, where some groups will be set up in opposition to others, especially "others" from elsewhere. There are active environmental groups in South Korea as part of a growing non-governmental organisation (NGO) movement (Choi \& Wright, 2004), but they are very much focused on isolated problems that are localised in nature. So, for example, if a group is organised to protest the placement of a new nuclear waste disposal site, they do not necessarily lend their expertise to other localities that may share the same problem. 


\subsection{Environmental Factors}

Environmental awareness cannot happen without some kind of shift in living conditions associated with a threat to public health or well-being (Downs, 1972). In South Korea, this awareness has been relatively slow to be realised, partly because of the breakneck pace of economic and industrial development over the past fifty years. As income levels rose with the arrival of trade and an industrial economy, concerns over air, soil, and water pollution took a backseat to simple improvements in living standards, including better nutrition and the associated health benefits (Chapin, 1969; Mkandawire \& Yi, 2014). If environmental pollution is seen as a reasonable trade-off for general well-being, populations are generally willing to make that trade. It has only been within the last twenty years or so that pollution levels and degradation have reached a point where the trade-off no longer seems justified.

In China, a similar economic developmental trajectory has taken place, but on a scale that dwarfs conditions in neighbouring states. Additionally, the communist continuum between economy and politics has served as both damper and catalyst for economic growth, industrialisation, and their subsequent environmental issues. When the central government finally committed itself to the current "marketisation" approach (Wang et al., 2014) as something that could be rolled out on a national basis for general benefit, the rate of national economic growth exploded, and the excessive levels of water, soil and air pollution soon followed. For China, the road to environmental awareness has been travelled with incredible speed, as has the general rise in income. But the two have not been seen in the same trade-off terms as witnessed in South Korea. This is partly because the general health of the Chinese population was relatively good prior to the rise in income. While health care was by no means universally high nor accessible across the country, one of the pillars of the legitimacy of the CCP was its ability to provide the previously completely destitute in rural areas with access to some basic improvements in health care (Bianco, 1971). Thus the association between improvements in health (longer life, better nutrition) and an industrialised urban economy were not as strong in China.

For this reason, there are somewhat similar levels of environmental awareness in both countries. This has been tied to general perceptions of declining quality of environmental factors, especially air quality, and the upheaval associated with rapid (and sometimes coerced) urbanisation. As 
the use of personal cars has risen in both countries, the associated air pollution levels in cities have risen, often exceeding thresholds hazardous to human health. China has also tapped its vast coal resources to provide power for a growing economy as cheaply as possible, in addition to the traditional practice of using coal to heat homes during the winter months. The combination of these factors has created air quality problems that have become a nearly constant reminder to citizens of both countries of the cost of progress.

\section{Exploratory Analysis}

In order to see whether the problems discussed above play out as centre-periphery issues, it is first necessary to see whether there is evidence that a policy distance measure can be created that captures the concept in a consistent fashion. The rationale for constructing such a measure will be explained, and then a simple test will be offered to see whether it performs as expected. A discussion of the results will follow.

In both countries, there has been a solid dedication to economic growth, and both China and South Korea have used a national political rhetoric that places a "market economy" front and centre in domestic policy rankings. The general lack of concern for environmental problems at the country level can easily be seen by examining national expenditures on "environmental policy problems". In both countries, the proportion of the national budget spent on "environmental problems" is consistently low (see Tables 1 and 2).

If anything, South Korea's concern for environmental issues has garnered far less support at the national level than is the case in China. Across administrations, from 1997 until 2011, the national government has consistently spent less than $1 \%$ of the national budget on environmental programs or concerns. However, there have been signs that this lack of attention takes a toll. Both countries have found themselves targets of 1) external criticisms by comparison: South Korea's ranking among OECD nations, for example, was close to absolute last in the late 1990s, only a few notches up from that of North Korea (Editorial, 2002), and 2) internal complaint, where, in Beijing, for example, the rise in popularity of "oxygen bars" in the mid-1990s was seen as the harbinger of a general call for air pollution mitigation by the government (Smith, 2000). 
Table 1: People's Republic of China, National Environmental Budget Expenditures as a Proportion of Total National Expenditures

\begin{tabular}{|c|c|c|c|c|c|}
\hline \multirow[b]{2}{*}{ Year } & \multicolumn{2}{|c|}{$\begin{array}{l}\text { National Government } \\
\text { Total Expenditures* }\end{array}$} & \multicolumn{2}{|c|}{$\begin{array}{c}\text { Environmental Expendi- } \\
\text { tures }\end{array}$} & \multirow{2}{*}{ 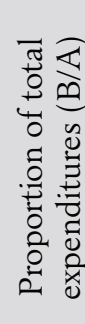 } \\
\hline & $\begin{array}{l}\text { Budget } \\
\text { (A) }\end{array}$ & 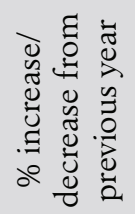 & Budget (B) & 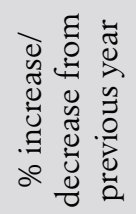 & \\
\hline 2003 & 18932 & & 1849.53 & & 0.10 \\
\hline 2004 & 21953.7 & 0.14 & 2217.91 & 0.17 & 0.10 \\
\hline 2005 & 25326.3 & 0.13 & 2846.19 & 0.22 & 0.11 \\
\hline 2006 & 29611.2 & 0.15 & 3049.95 & 0.07 & 0.10 \\
\hline 2007 & 37084.8 & 0.20 & 3939.39 & 0.23 & 0.11 \\
\hline 2008 & 45825.3 & 0.19 & 5479.67 & 0.28 & 0.12 \\
\hline 2009 & 56236 & 0.19 & 5701.01 & 0.04 & 0.10 \\
\hline 2010 & 89575 & 0.37 & 8009.17 & 0.29 & 0.09 \\
\hline 2011 & 108930 & 0.18 & 7558.39 & -0.06 & 0.07 \\
\hline 2012 & 125712 & 0.13 & 8753.92 & 0.14 & 0.07 \\
\hline 2013 & 139744 & 0.10 & 10384.2 & 0.16 & 0.07 \\
\hline
\end{tabular}

* Units are in 100 million yuan.

Source: Author's own, based on data from the National Bureau of Statistics, People's Republic of China.

In order to see whether my proposed measure of policy distance has any validity, this exploratory analysis will focus on the construction of the dependent variable and whether it exhibits different variance across the two countries. This can be problematic in China, because national policy pronouncements are made on an annual basis, but there are major policy restatements every five years. Similarly, in South Korea, a change in administration can signal a different emphasis on policy areas (see Table 2).

The choice of time frame is therefore important. Because this paper would like to explore how local governments align themselves as policy shifts at the national level, looking at a five-year period that spans two different policy regimes in both countries would be advisable. For this reason, data between 2004 and 2009 will be examined. In both South Korea and China, there was a shift in policy regime during this time. Therefore, the year 
Tao, J. L. (2016). Decentralising Unitary Governments Without a Map: Learning How to Salsa ... HKJU-CCPA, 16(4), 743-771

2007 is chosen as a year in which both countries were at similar points before the regime shifts.

Table 2: Republic of Korea, Environmental Expenditures as a Proportion of the National Budget, 1998-2011

\begin{tabular}{|r|l|c|c|c|r|}
\hline \multirow{2}{*}{ National budget and Environmental department (unit = 10 million won) } \\
\cline { 1 - 5 } Year & \multicolumn{2}{|c|}{ Government budget(A) } & \multicolumn{2}{c|}{$\begin{array}{c}\text { Environmental } \\
\text { department budget(B) }\end{array}$} & \multirow{2}{*}{$(\mathrm{B} / \mathrm{A})=\%$} \\
\cline { 2 - 5 } & Budget & $\begin{array}{c}\text { Increased } \\
\text { rate(\%) }\end{array}$ & Budget & $\begin{array}{c}\text { Increased } \\
\text { rate(\%) }\end{array}$ & \\
\hline 1998 & $1,344,939$ & & 11,131 & & 0.008 \\
\hline 1999 & $1,539,920$ & 14.4 & 11,536 & 3.64 & 0.0075 \\
\hline 2000 & $1,604,080$ & 4.1 & 13,023 & 12.89 & 0.008 \\
\hline 2001 & $1,617,387$ & 0.8 & 14,143 & 8.60 & 0.009 \\
\hline 2002 & $1,732,841$ & 7.1 & 14,336 & 1.36 & 0.008 \\
\hline 2003 & $1,880,037$ & 8.4 & 14,036 & -2.09 & 0.0075 \\
\hline 2004 & $1,943,554$ & 3.3 & 16,575 & 18.09 & 0.009 \\
\hline 2005 & $1,999,128$ & 2.8 & 28,557 & 72.29 & 0.0143 \\
\hline 2006 & $2,059,280$ & 3 & 29,991 & 5.02 & 0.0146 \\
\hline 2007 & $2,098,000$ & 1.8 & 32,231 & 7.47 & 0.0154 \\
\hline 2008 & $2,281,859$ & 8.7 & 35,914 & 11.43 & 0.0157 \\
\hline 2009 & $2,565,246$ & 12.4 & 40,282 & 12.16 & 0.0157 \\
\hline 2010 & $2,553,343$ & -0.4 & 44,832 & 11.30 & 0.0176 \\
\hline 2011 & $2,640,928$ & 3.4 & 47,778 & 6.57 & 0.0181 \\
\hline & & & & & \\
\hline
\end{tabular}

Source: Author's own, based on data from the Ministry of the Environment, Environmental Statistics Yearbooks, 1998-2011.

As argued by multiple political scientists, if one wishes to know what a government truly values, pay little attention to what politicians say - pay close attention to where they spend their money (Wildavsky, 1988; Edelman, 1967). For this reason, a measure of "policy distance" between the central and local governments is chosen as the difference in the proportion of the total budget spent on environmental concerns at the national and the local levels. The greater the "distance" between national and local priorities, the greater this difference should be. 


\subsection{Cases}

In order to create similar conditions for the behaviour of local officials, the cases in China were all chosen within one province in the northeast: Liaoning Province. This was done for a number of reasons: first, the province is roughly the size of Korea (145,900 square kilometres compared to 100,032 square kilometres), and second, it shares some geographical features that affect environmental conditions. It is a coastal province with both coastal and interior cities, each of which has distinctive economic and environmental concerns. Cities along the coast, like Dalian, have economies dependent on tourism and China's "second home" industry, where the cleanliness of the environment is key to the city's appeal to potential residents, especially those in the upper income brackets. Cities further inland, like Benxi and Shenyang, have economies that are heavily rooted in the industrial models of the steel and coal industries, so their approaches to environmental policy may be expected to be somewhat different if the policy distance between the centre and periphery allows for flexibility.

The cities in South Korea are drawn from all over the country, and the mix between coastal and interior cities is meant to capture the variety of approaches local governments may be inclined to take when adopting environmental policies. Cities on the eastern coast rely more heavily on fishing and tourism (like Sokcho), and therefore may be expected to spend more on programs related to maintaining high environmental standards than

O their more industrial counterparts in the northwest (such as Incheon) and the southeast (such as Ulsan, home to Hyundai Industries).

Because the number of large cities (with a population of over 1 million) in Liaoning Province is much higher than the number of large cities in Korea, the cities were chosen to roughly balance the proportion of coastal to interior cities, or approximately half ( 6 out of 14 in Liaoning, and 5 out of 10 in Korea). This is intended to pull a mix of local government incentives and interests from both countries that is roughly similar; more coastal cities will have an economy based on tourism and a "clean" appeal, while others will have an economy based on older industrial models.

\subsection{Data Caveats}

As might be expected, local budgets are political tools, and therefore are prone to heavy oversight by the national government, as well as by local 
interests. For this reason, there is some incentive on the part of local officials to ensure that expenditure reports are consistent rather than accurate. Thus the use of local budget expenditures, especially in China, where data is often considered suspect, may not be as reliable a measure of policy preferences as desired.

However, budget expenditures in both countries are reported on an annual basis, and there are ways to examine unusual behaviour, if any, fairly easily. The more troubling issue is the incentive to fit in. There is an oft-repeated expression in East Asia, "The stake that sticks up gets hammered down". The question here may be who the referent group is for comparison. This point will be raised again during the discussion of the data analysis and results.

\subsection{Preliminary Observations}

After collecting the budget data for all the cities in the study, I constructed a policy distance measure in the following way: $P_{D i}=\left[\left(\operatorname{PropEn}_{L i}\right)-\right.$ $\left.\left(\operatorname{PropEnv}_{N i}\right)\right]$ for each case, where PropEnv $v_{L}=$ the proportion of the local budget spent on environmental programs; and where PropEnv ${ }_{N}=$ the proportion of the national budget spent on environmental programs in a given year. Therefore, in a given country, policy distance could be measured for any given year by summing the square of $P_{D i}$, as follows: $P_{D K}=\sum_{i}\left(P_{D i}\right) .^{2}$ Thus if the policy distance measure for one country exceeds that for the other, one could say that for these cases, there is greater policy distance in environmental expenditures. This is basically the sum of squares over all the cases within a country context. Over several years, one could take the average policy distance if this seemed appropriate given the distribution of data across time and cases.

For example, for the year 2007, I calculated the following for the cases in Korea and northeastern China (see Table 3).

The first point worth noting is that there is far more uniformity across the Chinese cases than there is across the Korean cases. This is what one might expect given the nature of a communist regime. However, there is greater distance from the national benchmark in China than there is in Korea, indicating that although Korean cities may vary more across localities, they do not stray as far from the national centre as their Chinese counterparts. It is also worth noting that Korean cities on average tend to spend a greater proportion of their local budgets on environmental con- 
cerns than the national government, where Chinese cities spend less. This seems to lend support to the hypothesis that local governments within the two countries orient themselves differently, both towards each other and the national government.

Table 3: Policy Distance in 2007 for South Korea and Liaoning Province, China (Korean cities are in italics)

\begin{tabular}{|c|c|c|c|c|}
\hline City & $\begin{array}{l}\text { Local Env'l } \\
\text { Proportion }\end{array}$ & $\begin{array}{l}\text { National Env'l } \\
\text { Proportion }\end{array}$ & $\mathrm{P}_{\mathrm{Di}}$ & $\mathrm{P}_{\mathrm{DK}}$ \\
\hline Sokcho & 0.173546499 & 0.015362726 & 0.158183773 & \multirow[t]{10}{*}{0.094165492} \\
\hline Sbinan & 0.170813208 & 0.015362726 & 0.155450482 & \\
\hline Andong & 0.064656635 & 0.015362726 & 0.049293909 & \\
\hline Jeju & 0.10678364 & 0.015362726 & 0.091420914 & \\
\hline Ulsan & 0.128473042 & 0.015362726 & 0.113110316 & \\
\hline Daegu & 0.018538492 & 0.015362726 & 0.003175765 & \\
\hline Daejeon & 0.03131508 & 0.015362726 & 0.015952353 & \\
\hline Busan & 0.002150366 & 0.015362726 & -0.01321236 & \\
\hline Incheon & 0.030611146 & 0.015362726 & 0.01524842 & \\
\hline Seoul & 0.159325477 & 0.015362726 & 0.14396275 & \\
\hline Shenyang & 0.013581201 & 0.106226566 & -0.092645364 & \multirow[t]{13}{*}{0.113490962} \\
\hline Dalian & 0.012689336 & 0.106226566 & -0.09353723 & \\
\hline Anshan & 0.011416422 & 0.106226566 & -0.094810144 & \\
\hline Benxi & 0.018888453 & 0.106226566 & -0.087338112 & \\
\hline Dandong & 0.012542555 & 0.106226566 & -0.09368401 & \\
\hline Jinzhou & 0.016752547 & 0.106226566 & -0.089474019 & \\
\hline Yingkou & 0.013202721 & 0.106226566 & -0.093023845 & \\
\hline Fuxin & 0.009975792 & 0.106226566 & -0.096250773 & \\
\hline Liaoyang & 0.010087051 & 0.106226566 & -0.096139514 & \\
\hline Panjin & 0.011529522 & 0.106226566 & -0.094697043 & \\
\hline \begin{tabular}{|l|} 
Tieling \\
\end{tabular} & 0.01365836 & 0.106226566 & -0.092568205 & \\
\hline Chaoyang & 0.011802572 & 0.106226566 & -0.094423994 & \\
\hline Huludao & 0.010588523 & 0.106226566 & -0.095638042 & \\
\hline \multicolumn{5}{|c|}{$\begin{array}{l}\text { Source: Author's own, based on data from the National Bureau of Statistics, People's Re } \\
\text { public of China }\end{array}$} \\
\hline
\end{tabular}




\section{Discussion and Next Steps}

Although there appears to be preliminary support for the idea that local governments in the two countries orient themselves differently (South Korea towards the centre and China towards peers), explaining why this might be the case is necessary. Two main reasons are offered. The first would be cultural. Although both countries share historical ties and common cultural characteristics, the twentieth century saw substantial divergence between the two nations in a particularly notable way. Within China, under the rule of former CCP Chairman Mao Zhedong, there was a wholesale rejection of Confucian teaching and norms, which Mao saw as antithetical to the modernisation of the Chinese state. Unlike China, Japan and South Korea kept Confucian principles relatively intact throughout governing institutions and structures (Choi, Hong \& Wright, 2010). This distinction would lead one to conclude that Korean officials would be more likely to behave in ways that demonstrate Confucian notions of propriety and loyalty than their Chinese counterparts. Part of propriety would be accepting one's position in society and the authority of one's superiors without question. ${ }^{5}$ In Mao's China, such ideas were roundly criticised and attacked as "feudal thinking", especially during the Cultural Revolution (Bianco, 1971). This rejection of Confucian norms, especially the shifting of the basis for determining authority, led to an upheaval in the social structure that has lingered (Fewsmith, 2000).

The second reason would be ideological. As mentioned previously, the importance of ideology in China transcends many other influential variables. In South Korea, ideology has been somewhat subsumed by the rise of competing political parties, so there are clearer indicators of what the prevailing leaning of the ruling class might be. But in China, because there is only the CCP, determining such leanings is much more difficult, both for public officials and for researchers. Thus there are different pressures within the two systems that lead to different orientations among public officials with respect to centre-periphery relations. In South Korea, the continuation of Confucian norms orients officials towards the central government. However, the expectation is that each locality will petition the central government for the status of "favourite child". However, be-

\footnotetext{
${ }^{5}$ It should be noted that accepting one's place in society and the authority of one's superiors does not necessarily mean uncritical acceptance. In South Korean neo-Confucian approaches to governing, officials were often critical of behaviour they saw as contrary to Confucian doctrine, even if that behaviour came from higher quarters (Kim, 2012).
} 
cause the central government may change priorities when administrations change (which is now required because no president can stand for re-election), the role of "favourite child" will move as power at the centre shifts. Thus the relationship that matters most in terms of discretionary privileges is the one between the central government and the local government (Kim, 2012).

In China, although there are shifts at the centre, the relative importance of different policy areas is far more subtle, and any changes must go through an important level prior to reaching local governments: the provincial level. The relationships, therefore, are structurally different and are meant to be far less discretionary in impact. Thus figuring out what the centre intends means going beyond what is stated officially, or even what the national budget suggests priorities might be. Therefore, I propose the following hypotheses for future research:

$H y p_{0}$ : There is no difference between the variance of local environmental budget allocations across local governments between China and South Korea, or $\operatorname{Var}(\mathrm{C})=\operatorname{Var}(\mathrm{K})=0$.

In other words, there will not be a significant difference across local government jurisdictions in terms of local budget allocations in either country, signifying relative comportment in line with the central government's directives.

$H y p_{A 1}$ : The variance of local budget environmental allocations in South Korea will be greater across local governments than in China, because less attention is paid to peer behaviour.

$H y p_{A 2}$ : The influence of interest groups on local budget allocation will be mediated by a political party in South Korea, but not in China.

$H y p_{A 3}$ : Local environmental conditions (such as levels of air pollutants) will have a greater influence on local budget behaviour in Korea than in China (response to electorate).

In other words, if the majority of seats on the local government council are held by the same party which is in power at the national level, then local interest groups with policy agendas contrary to those of the party in power will have a reduced impact on budget allocations in the desired directions. This may, however, be affected by high levels of air pollution in South Korea, where local officials can be removed from office by a dissatisfied latent public, but not in China, where such removal would not necessarily be seen as affecting the problem.

These hypotheses address the orientation of local governments towards each other and towards the centre, but thus far the concept of policy dis- 
tance has just been demonstrated, not incorporated. If the local government is closer to the centre in its policy orientation, as appears to be the case in South Korea, then the impact of local factors, such as economic disparity or the influence of interest groups (Lim \& Tang, 2002), will be relatively diminished. However, the distinction between the centre and the periphery in terms of policy adherence can be problematic if the poli$c y$ is outlined in very general or vague language. In China, this is often the case, because the wording of a policy can be fraught with symbolic implications, and there are multiple groups who are looking for shifts, however imperceptible they may be to an outsider, in the policy orientation of the CCP (Fewsmith, 2000). So, how do we overcome this problem?

One possibility is, of course, that the idea of physical distance as well as political and administrative distance can create distortions in the way in which central policies are understood. If there are certain norms that are shared across groups (such as party solidarity or a strong civil service), these can shorten policy distance. Additionally, physical proximity can mean oversight from the centre is easier and monitoring costs are reduced. If a given local government has relatively little policy distance from the centre, then one might expect the proportion of budget allocations to follow the central government's proportions fairly closely. With these ideas in mind, I propose the following hypotheses:

$H y p_{0 a}$ : There will be no significant difference between the proportion of budget allocations for environmental policy at the national and local levels.

$H y p_{A 1 a}$ : There will be a significant difference between the proportion of budget allocations for environmental policy at the national and local levels when local environmental conditions are significantly worse than the national average.

$H y p_{A 2 a}$ : There will be a significant difference between the proportion of budget allocations for environmental policy at the national and local levels when local political party affiliation is different from the national majority. $H y p_{A 3 a}$ : There will be a negative relationship between the strength of the civil service and the difference between the proportion of budget allocations for environmental policy at the national and local levels.

In order to test these hypotheses, and perhaps better refine the measure of policy distance, more data will need to be collected. But should additional tests continue to support the preliminary results reported here, there are important implications for some of the general suppositions in the literature about the nature of centre-periphery relations in political and economic systems. 


\section{Conclusion}

The notion that there is a clear correlation between the degree of autonomy granted to local governments and the degree to which those local governments may respond to central directives has been re-examined in light of the Korean and Chinese contexts. The importance of ideology in both contexts and the different effects of Confucian cultural constructs may account for the difference in behaviour across national boundaries in a manner unexplored within the traditional variables borrowed from the literature in the West. For these reasons, distance from the centre to the periphery is important to measure, but the conclusions we draw about decentralisation in unitary environments should be offered with care. Our theoretical toolkits may not always travel as well as we would like them to.

\section{References}

Berry, F. S., \& Berry, W. D. (1990). State lottery adoptions as policy innovations: An event history analysis. American Political Science Review, 84 (3), 395-415.

Bianco, L. (1971). Origins of the Chinese revolution: 1915-1949 [Translated by Muriel Bell]. Palo Alto, CA: Stanford University Press.

Bristow, M. (2011). Chinese leader rules out democracy. Retrieved from http://www. bbc.com/news/world-asia-pacific-12697997

Chapin, E. (1969). Success story in South Korea. Foreign Affairs, 47(3). Retrieved from http://www.foreignaffairs.com/articles/24078/emerson-chapin/successstory-in-south-korea

Chen, W., Zheng, R., Zeng, H., \& Zhang, S. (2015). Epidemiology of lung cancer in China. Thoracic Cancer, 6(2), 209-215. doi: 10.1111/1759-7714.12169

Cho, C., Hong, J., \& Wright, D. S. (2010). Intergovernmental relations in Korea: From dependency to interdependency. In E. Berman, M. Jae Moon, and H. Choi (Eds.) Public administration in East Asia: Mainland China, Japan, South Korea, and Taiwan (pp. 377-400). New York, NY: CRC Press.

Choi, Y. S., \& Wright, D. S. (2004). Intergovernmental relation (IGR) in Korea and Japan: Phases, patterns, and progress toward decentralisation (local autonomy) in a trans-pacific context. International Review of Public Administration, 9(1), 1-22.

Clingermayer, J. C., \& Feiock, R. C. (2001). Institutional constraints and policy choice: an exploration of local governance. Albany, NY: State University of New York Press.

Dahl, R. H. (1961). Who governs? Democracy and power in an American city. New Haven, CT: Yale University Press. 
Downs, A. (1972). Up and down with ecology: The 'issue-attention cycle'. The Public Interest, 28 (Summer), 38-50.

Edelman, M. (1967). The symbolic uses of politics. Champagne-Urbana, IL: University of Illinois Press.

Editorial (2002). Poor environmental sustainability. Chosun Ilbo, Feburary 5, English edition. Seoul, Republic of Korea.

Feiock, R. C., Francis, N. \& Kassekert, T. (2010, December). Explaining the adoption of climate change policies in local government. Paper presented at the Pathways to Low Carbon Cities Workshop, Hong Kong, People's Republic of China.

Greenpeace (2016). Clean air action plan: The way forward. Bangalore, India: Greenpeace India.

Im, T. B., Campbell, J. W., \& Cha, S. Y. (2013). Revisiting Confucian bureaucracy: Roots of the Korean governments' culture and competitiveness. Public Administration and Development, 33, 286-296.

Johansson, J., Niklasson, L., \& Persson, B. (2015). The role of municipalities in the bottom-up formation of a meta-region in Sweden: Drivers and barriers. Scandinavian Journal of Public Administration, 19(4), 71-88.

Jung, K.-W., Park, S., Kong, H.-J., Won, Y.-J., Lee, J. Y., Seo, H. G., \& Lee, J.-S. (2012). Cancer statistics in Korea: Incidence, mortality, survival, and prevalence in 2009. Cancer Research and Treatment: Official Journal of Korean Cancer Association, 44(1), 11-24. doi: 10.4143/crt.2012.44.1.11

Kim, P. S. (2012). A historical overview of Korean public administration: discipline, education, association, international cooperation, and beyond indigenization. International Review of Administrative Sciences, 78(2), 217-238.

Kwok, S.-J., Yoo, S.-H., \& Chul O. (2002). A multiattribute index for assessing environmental impacts of regional development projects: A case study of Korea. Environmental Management, 29(2), 301-309.

Lee, S.-K. (1998). Environmental law. Seoul, Korea: Bub-Moon Sa.

Lee, B.-W., Kim, G.-C., \& Ahn, Y.-G. (1999). Environmental management system in Korea. Environmental Policy [translated from Chinese], 7(1), 47.

Li, L. C. (2010). Central-local relations in the People's Republic of China: Trends, processes and impacts for policy implementation. Public Administration and Development, 30, 170-190.

Lim, J. H., \& Tang, S. Y. (2002). Democratization and environmental policy-making in Korea. Governance, 15(4), 561-582.

Lowi, T. (1969). The end of liberalism. New York, NY: W. W. Norton and Company.

Ministry of Environment, Republic of Korea. (2015). History of MOE. Sejong City. Retrieved from http://eng.me.go.kr/eng/web/index.do?menuId=6\&findDepth $=1$

Ministry of Environment, Republic of Korea. (1998). Environmental statistics yearbook. Seoul. 
Ministry of Environment, Republic of Korea. (1999). Environmental statistics yearbook. Seoul.

Ministry of Environment, Republic of Korea. (2000). Environmental statistics yearbook. Seoul.

Ministry of Environment, Republic of Korea. (2001). Environmental statistics yearbook. Seoul.

Ministry of Environment, Republic of Korea. (2002). Environmental statistics yearbook. Seoul.

Ministry of Environment, Republic of Korea. (2003). Environmental statistics yearbook. Seoul.

Ministry of Environment, Republic of Korea. (2004). Environmental statistics yearbook. Seoul.

Ministry of Environment, Republic of Korea. (2005). Environmental statistics yearbook. Seoul.

Ministry of Environment, Republic of Korea. (2006). Environmental statistics yearbook. Seoul.

Ministry of Environment, Republic of Korea. (2007). Environmental statistics yearbook. Seoul.

Ministry of Environment, Republic of Korea. (2008). Environmental statistics yearbook. Seoul.

Ministry of Environment, Republic of Korea. (2009). Environmental statistics yearbook. Seoul.

Ministry of Environment, Republic of Korea. (2010). Environmental statistics yearbook. Seoul.

Ministry of Environment, Republic of Korea. (2011). Environmental statistics yearbook. Seoul.

Minkoff, S. L. (2012). The proximate polity: Spatial context and political risk in local developmental goods provision. Urban Affairs Review, 48(3), 354-388.

Mkandawire, T., \& Yi I. (2014). Overview: Learning from developmental success. In T. Mkandawire \& I. Yi (Eds.), Learning from the South Korean developmental success: Effective developmental cooperation and synergistic institutions and policies (pp 1-9). Hampshire, UK: Palgrave Macmillan \& UNRIDS.

Muramatsu, M. (1997). Local power in the Japanese state [Translated by Betsey Scheiner and James White]. Berkeley, CA: University of California Press.

Nakamura, R., \& Smallwood, F. (1980). The politics of policy implementation. New York, NY: St. Martin's Press.

Neimeijer, D. (2002). Developing indicators for environmental policy: data-driven and theory-driven approaches examined by example. Environmental Science and Policy, 5, 91-103.

Peters, B. G., Schroter, E. \& von Maravic, P. (2015). The comparative study of representative bureaucracy: An analytical framework. In B. G. Peters, P. von Maravic, \& E. Schroter (Eds.), Politics of representative bureaucracy: Power, legitimacy and performance (pp. 24-40). Cheltenham, UK: Edward Elgar Publishing. 
Peterson, P. (1981). City limits. Chicago, IL: University of Chicago Press.

Peterson, P. (1995). The price of federalism. Washington D.C.: The Brookings Institution.

Republic of Korea. (2006). National strategy for sustainable development of the Republic of Korea. Seoul: Republic of Korea.

Saikawa, E. (2014). China's war on air pollution. China Currents, 13(2), Article 5. Retrieved from http://www.chinacentre.net/category/china_currents/13-2/ chinas-war-on-air-pollution

Smith, Z. A. (2000). The environmental policy paradox. New York, NY: Prentice Hall.

Stone, C. (2008). Urban politics, then and now. In M. Orr \& V. Johnson (Eds.), Power in the city: Clarence Stone and the politics of inequality. Lawrence, KS: University of Kansas Press.

Strebel, H., \& Lehman, J.-P. (2013). London and Beijing: A polluted tale of two cities. Retrieved from http://www.theglobalist.com/london-beijing-polluted-tale-two-cities/

Sun H. (2014). Interviews in Incheon, South Korea on November 15 and December 3 .

Tao, J. L., \& Feiock, R. C. (1999). Directing benefits to need: Evaluating the distributive consequences of urban economic development. Economic Development Quarterly, 13(1), 55-65.

Tavares, A., \& Carr, J. B. (2013). So close, yet so far away? The effects of city size, density and growth on local civic participation. Journal of Urban Affairs, 35(3), 255-392.

Tiebout, C. (1956). A pure theory of local expenditures. Journal of Political Economy, 64, 416-424.

Volunteers in Asia (VIA) (1989). Interview with Curtis, Benxi representative, in Xi'an city, January 10.

Wang, M., C., Zhiming, Z., P., Tong, L., \& Ma, Y. (2014). Old industrial cities seeking new road of industrialization: Models of revitalizing northeast China. Singapore, Republic of Singapore: World Scientific Publishing.

Wildavsky, A. (1988). The new politics of the budgetary process. Glenview, IL: Scott-Foresman/Little Brown Publishers.

Wright, D. R. (1978). Understanding intergovernmental relations. North Scituate, MA: Duxbury Press. 


\section{DECENTRALISING UNITARY GOVERNMENTS WITHOUT A MAP, OR LEARNING HOW TO SALSA WHEN WE ONLY KNOW HOW TO WALTZ}

\section{Summary}

This paper examines disparities between unitary central governments and local governments in how environmental policy is defined and implemented at the local level. This is done within the context of northeast Asia, where results can often differ from expectations driven by traditional models of local government behaviour offered by the West. The author constructs a theoretical measure for policy distance between the central government and its subsidiaries and then operationalise the measure in a comparative context within northeastern China and the Republic of Korea. Because of their proximity, these regions share environmental concerns that cross international boundaries, and both countries have gone through an unusually rapid decentralisation of decision-making within the environmental policy arena. This has produced a range of responses to environmental concerns at the local level, allowing for a comparative examination of the relative importance of structural, political, and economic constructs with regard to policy expenditures. Using local and national budget data from 23 cities with bistories of environmental issues (13 in northeast China and 10 in South Korea), the author's measure of policy distance between the centre and the periphery is tested. It is found that, contrary to traditional model expectations, there is far greater concurrence between local governments and the national government within a democratic nation than there is within a communist one.

Keywords: decentralisation, local government, China, South Korea, policy distance 
Tao, J. L. (2016). Decentralising Unitary Governments Without a Map: Learning How to Salsa ...

HKJU-CCPA, 16(4), 743-771

\section{DECENTRALIZACIJA UNITARNIH DRŽAVA BEZ ZEMLJOPISNE KARTE: KAD PLESAČI VALCERA UČE SALSU}

\section{Sažetak}

U radu se razmatra kako središnja vlast unitarne države tumači i provodi politiku upravljanja okolišem na lokalnoj razini te kako to čini njezina lokalna samouprava. Kontekst je sjeveroistočna Azija gdje se konkretni rezultati često ne poklapaju sočekivanjima nametnutima proučavanjem tradicionalnib obrazaca koje slijede lokalne samouprave u zapadnim zemljama. Autorica predlaže način mjerenja policy distance (udaljenosti kod stvaranja politika) izmedu središnje vlasti $i$ podredenih jedinica te ga primjenjuje u usporednom kontekstu sjeveroistočne Kine i Republike Koreje. Ta su dva područja zemljopisno bliska te ih povezuju problemi okoliša koji nadilaze medunarodne granice. Također, obje su zemlje doživjele neuobičajeno brz proces decentralizacije politike upravljanja okolišem. To je na lokalnoj razini dovelo do različitib reakcija na probleme okoliša te je omogućilo usporedbu relativne važnosti strukturnih, političkib i ekonomskib pitanja s obzirom na troškove provedbe politike upravljanja okolišem. U radu su korišteni podaci lokalnog $i$ državnog proračuna za 23 grada koji imaju dugogodišnje probleme s upravljanjem okolišem (13 gradova u sjeveroistočnoj Kini i 10 u Južnoj Koreji) te se pomoću tib podataka testira prijedlog autorice kako izmjeriti policy distancu izmedu centra $i$ udaljenib jedinica. Unatoč očekivanjima zasnovanima na tradicionalnom modelu, rezultati upućuju na daleko veće slaganje lokalne samouprave $i$ državne vlasti u demokratskoj državi nego u komunističkom sustavu.

Ključne riječi: decentralizacija, lokalna samouprava, Kina, Južna Koreja, policy distanca 
